\title{
Dual-Class Firms' Choice of Performance Measures \\ in CEO Stock Compensation Contracts
}

by

$\mathrm{Ji} \mathrm{Li}$

\section{A Dissertation Presented in Partial Fulfillment of the Requirements for the Degree \\ Doctor of Philosophy}

Approved April 2014 by the Graduate Supervisory Committee:

Michal Matějka, Chair

Philip Reckers

Yuhchang Hwang

\section{ARIZONA STATE UNIVERSITY}

May 2014 


\begin{abstract}
This study provides new evidence on the choice of performance measures used in dual-class firms to incentivize CEOs. The choice of performance measures is informative about the extent to which the board of directors focuses CEO efforts on firms' long-term versus short-term objectives. To empirically operationalize performance evaluation horizon, I measure the length of the performance evaluation period in CEO stock awards, the use of stock-based measures, and the use of peer-based measures. I collect data on 419 dual-class firms and match them with a control group of single-class firms. I find that market-based metrics are less likely to be used by dual-class firms relative to single-class firms. In addition, I find that peer-based measures are much less common for dual-class than single-class firms. These findings suggest that dual-class firms shield their executives from short-term market pressures and design stock compensation contracts that deemphasize volatile stock prices.
\end{abstract}




\section{ACKNOWLEDGMENTS}

I am especially grateful to my dissertation committee for their invaluable guidance and assistance on this paper: Michal Matějka (chair), Yuhchang Hwang, and Philip Reckers. I would also like to thank Artur Hugon for his feedback. I would like to thank Vanessa Makridis and Deborah McBride for their insightful comments. I would also like to thank the workshop participants at Arizona State University for their helpful remarks. 


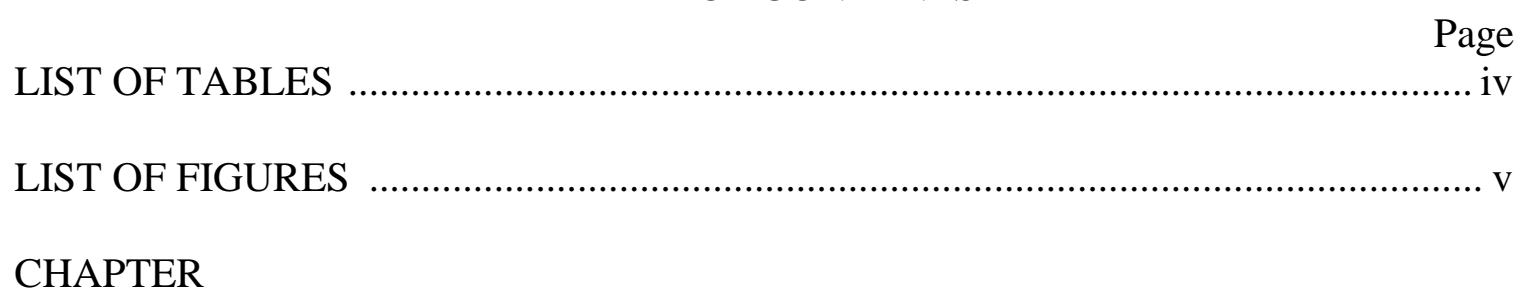

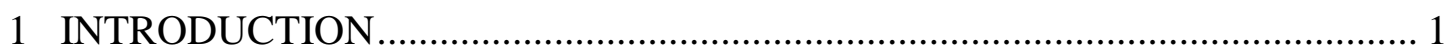

2 LITERATURE REVIEW AND HYPOTHESIS DEVELOPMENT ..................... 6

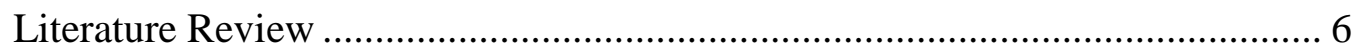

Hypothesis Development ................................................................

3 SAMPLE SELECTION, VARIABLES, AND DESCRIPTIVE STATISTICS .....11

Sample Selection for the Dual-Class and Single-Class Samples .....................11

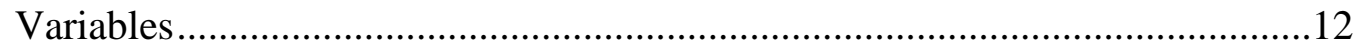

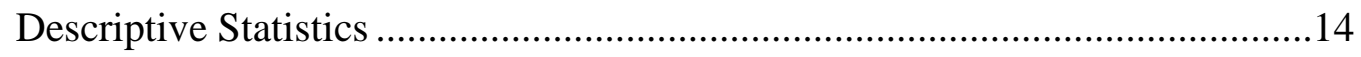

4 RESEARCH DESIGN AND RESULTS .....................................................

Matching Analysis.............................................................................16

Regression Models ..........................................................................17

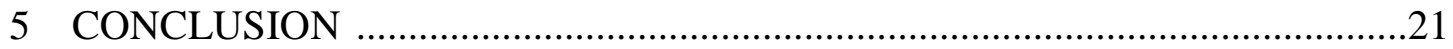

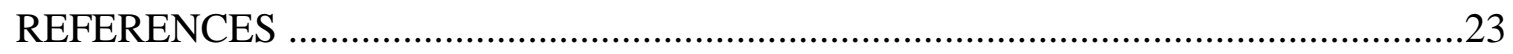

\section{APPENDIX}

A EXCEPT FROM COUNCIL OF INSTITUTIONAL INVESTORS (CII)'S

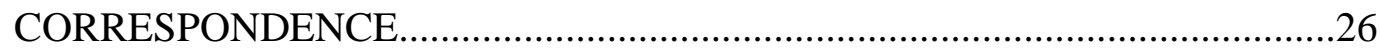

B EXCERPT FROM YAHOO NEWS ...........................................................28 


\section{LIST OF TABLES}

Table

1. Descriptive Statistics for Dual-Class Firms, Single-Class Firms and S\&P 1500

Firms 30

2. CEO Compensation Contract Comparison for Dual-Class and Single-Class

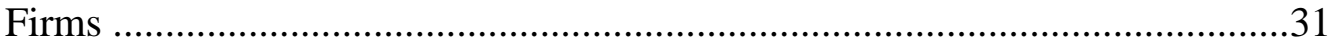

3. Propensity Score Matching Analysis on Performance Measure Choices........32

4. Regression Analysis on the Length of Performance Evaluation Period .......... 33

5. Logistic Model on the Use of Market-Based Performance Measures ............. 34

6. Logistic Model on the Use of Peer-Based Performance Measures ...................35 


\section{LIST OF FIGURES}

Figure

1. Distribution of CEO Stock Ownership for Dual-Class Firms................................ 36

2. Distribution of CEO Stock Ownership for Single-Class Firms.............................. 36

3. Distribution of CEO Stock Ownership for S\&P 1500 Firms.................................. 36

4. Another Presentation of Distribution for Dual-class, Single-class Firms and S\&P 1500

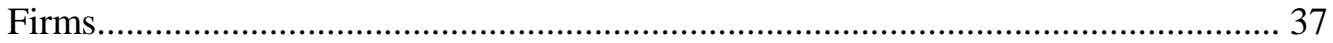


Chapter 1

\section{INTRODUCTION}

A large stream of academic work has examined the effect of dual-class structures on firm value and performance. ${ }^{1}$ Some studies find that the separation of ownership and control inherent in dual-class structures leads to lower firm value and poor performance (Gompers, Ishii, and Metrick, 2009), while there also is evidence suggesting that dualclass structures enhance firm value (Dimitrov and Jain 2006). Numerous high-profile companies have chosen a dual-class stock structure in recent years-underscoring the importance of the issue in practice. Institutional investors especially, have been concerned about multiple classes of stock with disparate voting rights, and complain that dual-class stock companies limit their ability to press boards and executives to institute real changes (Byrd 2012; see Appendix A).In contrast, dual-class companies argue that their structures allow them to more effectively focus on long-term value creation (see Appendix B).

This study revisits this question by looking at the design of executive compensation and provides new evidence on the choice of performance measures in dualclass firms. The choice of performance measures is informative about intentions of the board of directors and about the extent to which CEOs are incentivized to focus on firms' long-term versus short-term objectives. In this regard, CEO stock compensation

\footnotetext{
${ }^{1}$ Dual-class firms issue two classes of common stock, designated as inferior stock and superior stock, or Class A and Class B shares. The inferior stock has one vote per share while superior stock has multiple voting rights. Although these two classes of shares represent the same underlying ownership in the company, the non-publicly traded superior shares have greater voting rights per share and thus more control.
} 
arrangements provide an ideal setting to examine the purpose of dual-class stock structures.

There are two main theoretical explanations of dual-class structures. On the one hand, the managerial power theory holds that dual-class structures misalign economic incentives and voting power and thus disadvantage outside shareholders (Bebchuk, Fried, and Walker 2002). On the other hand, optimal contracting theory holds that adoption of a dual-class structure allows managers to enhance shareholder value over the long-run (Core and Larcker 2003, Amoako-Adu, Baulkaran, and Smith 2011). Specifically, it asserts that outside shareholders face information asymmetry about the firm and are unable to make informed choices about strategic initiatives. In contrast, company founders or other insiders of dual-class firms are able to innovate and exploit long-run product cycles for the benefit of shareholders. Firm value suffers if insiders are subjected to short-term market pressures. Thus, company founders or other insiders are said to need more voting power to better exploit their private information for the benefit of all shareholders.

To the extent that the optimal contracting view holds, I expect performance measures in executive contracts of dual-class firms to reflect long performance evaluation horizons, which incentivize CEOs to focus on strategic initiatives and shield them from short-term market pressures. In contrast, if executives self-servingly influence the design of compensation contracts and dual-class structures facilitate managerial entrenchment, I expect performance measures to have a short horizon. Short-term performance measures are more easily controlled or manipulated by executives and thus should lead to higher compensation. 
I examine several characteristics of performance measures in CEO stock awards to empirically operationalize performance evaluation horizon. Specifically, I measure the length of the performance evaluation period, the use of stock-based measures, and the use of peer-based measures. Furthermore, I focus on the choice of performance measures in stock awards as opposed to other compensation components for the following reasons. First, stock awards account for a considerable share of executives' total compensation and thus are economically significant to both the firm and the CEO. Second, unlike cash bonuses or salary, which are backward-looking and short-term oriented, stock awards spanning multiple years are forward-looking and potentially long-term oriented.

I hand collect data on CEO compensation contracts from proxy statements filed with the SEC from 2007 to 2011 for all U.S. dual-class firms in the S\&P 1500to assess whether dual-class firms choose performance measures differently than do single-class firms. Due to increased firm disclosure requirements implemented by the SEC in 2006, I am able to use this data to examine contractual features of performance measures in executives’ equity awards, particularly performance-contingent equity awards. ${ }^{2}$ Such contract features include the length of the performance evaluation period, whether the specific performance metrics employed are stock-based, and the use of absolute or relative benchmarks (RPE). My main sample consists of 419 U.S. dual-class firms and a matched control group of single-class firms.

\footnotetext{
${ }^{2}$ Since 2006, the SEC has required firms to disclose executive compensation in more details in the newly created section called "Compensation Discussion and Analysis" (CD\&A) in their proxy statements. The SEC's executive compensation disclosure rules require detailed information on how executive compensation is determined.
} 
My main findings are as follows. First, I find that market-based metrics are less likely to be used by dual-class firms relative to single-class firms: $37.1 \%$ of single-class firms in my sample use market-based metrics, while only $8.8 \%$ of dual-class firms use them. Second, I find that peer-based measures are much less common for dual-class than single-class firms. In particular, I find that only $6.9 \%$ of dual-class firms use peer-based metrics as compared to $26.4 \%$ of single-class firms. My findings suggest that adoption of a dual-class structure is consistent with shielding CEOs from short-term market pressures with regard to their long-term strategic business decision making. Avoiding the use of stock-based measures reduces the pressure on CEOs to meet quarterly earnings targets and to manage analysts' quarterly forecasts. Similarly, avoiding the use of peer-based metrics alleviates the pressure to compete with peers that may be overly focused on pursuing short-term stock returns.

My results contribute to prior literature in three ways. First, while prior compensation studies have focused on the consequences of compensation contract choices, such as the comparison of total compensation amount in dual-class firms with the total compensation amount in single-class firms, far less work has been done to study the determinants of compensation contracts. My study fills in this void and highlights that the choice of single- versus dual-class structures is an important driver of compensation design.

Second, prior literature seldom controls for CEO stock ownership even though it is an important determinant of other compensation choices and varies considerably between dual-class and single-class firms. In theory, executives with greater equity stakes have greater incentives to build economic value, as actions impairing firm value would 
do damage to the executive's personal wealth (Larker and Tayan 2011). Therefore, this study matches dual-class firms to a control group of single-class firms that are similar in terms of CEO stock ownership.

Finally, my findings suggest that dual-class firms shield their executives from short-term market pressures and design compensation contracts that deemphasize volatile stock prices. Although these findings do not necessarily favor the optimal contracting view over the managerial entrenchment view (or vice versa), they nevertheless inform the debate about the purpose of dual-class firms.

The remainder of this paper proceeds as follows. Section 2 develops relevant hypotheses and places my paper in the context of related research. Section 3 describes how the sample data is generated and compares dual-class and non-dual-class firms on certain dimensions of stock awards. Section 4 reports the analysis and results and Section 5 provides concluding remarks on my findings. 
Chapter 2

\section{LITERATURE REVIEW AND HYPOTHESIS DEVELOPMENT}

\subsection{Literature Review}

Multiple prior studies have investigated the effects of dual-class ownership structures on the quality of disclosures, the informativeness of earnings and dividend policy, business investment decisions, and executive compensation. Overall, prior research does not provide consistent evidence that dual-class structures either benefit or harm ordinary shareholders.

One stream of literature asserts that dual-class firms are more prone to pursue private benefits at shareholders’ expense. Francis, Schipper and Vincent (2005) compare the informativeness of earnings for firms with dual-class and single-class equity structures, and the findings show that earnings are generally less informative for dualclass firms. Dual-class structures are deemed to reduce the credibility of earnings. Gompers, Ishii and Metrick (2009) find that during the period from 1994 to 2002, dualclass firms perform worse than comparable firms for which all shares confer equal voting rights. They also report that dual-class firms' value is increasing in insiders' cash-flow rights and decreasing in insider voting rights. Bebchuk, Kraakman, and Triantis (2000) argue that dual-class equity can create agency costs an order of magnitude larger than the costs associated with a controlling shareholder who also has a majority of the cash flow rights in the corporation.

Another stream of literature finds that a dual-class equity structure has economic benefits. Dimitrov and Jain (2006) show that recapitalization of one class of common stocks into restricted voting stocks is a value enhancing initiative for the general 
shareholders. Claessens et al. (2000) find that the negative association between issuance of dual-class shares and corporate valuation reported in prior studies is not statistically significant, and do not find evidence that the issuance of dual-class shares separating ownership and control is associated with the valuation discount.

Closely related to my work are several studies that examine dual-class stock structure from the standpoint of executive compensation. Masulis, Wang and Xie (2009) find that divergence between insider voting and cash flow rights increases managerial extraction of private benefits of control. Specifically, they find that when the divergence between cash flow rights and voting rights widens at dual-class companies, (a) CEOs receive higher compensation and (b) capital expenditures contribute less to shareholder value. Further, they report that the bigger the divergence, the greater the rent extraction. Amoako-Adu, Baulkaran, and Smith (2011) show that family members in executive positions in dual-class companies are paid significantly more than executive family members in single-class companies with concentrated control.

Still, from the perspective of executive compensation, some studies confirm the merits and rationality of dual-class structures. Gomez-Mejia and Wiseman (1997), Grabke-Rundell and Gomez-Mejia (2002), and Core and Larker (2002) test whether executives are given incentive-based compensation to align their interests with those of outside shareholders, which would be consistent with optimal contract theory. They find that executives receive higher compensation in dual-class firms than in single-class firms, and this higher compensation is to prevent dual-class executives from taking advantage of their higher voting leverage. 
However, many extant studies comparing dual-class and single-class firms lack controls for CEO stock ownership, which is likely a confounding factor affecting their results. Thus, in this study, I control for CEO stock ownership to conduct a more rigorous test. Details are discussed in Section 3.

\subsection{Hypothesis Development}

I examine the effect of dual-class structure on three design features of CEOs' performance-vested stock awards: the length of the performance evaluation period, the use of market-based performance measures, and the use of relative performance measures.

First, an important feature of long-term incentive awards is the length of the period over which performance is measured. A short performance period may promote short-term myopic and opportunistic behavior or even encourage managers to manipulate their performance measures (Mizik 2010; Dallas 2012). If the goal of dual-class structures is to promote long-term focus, then the use of short-term performance measures is difficult to justify. Conversely, a long performance period that eliminates unwanted short-term market fluctuations and better coincides with long-term strategic business decisions seems congruent with the contracting justification of dual-class structures. Thus, I hypothesize:

H1: Compared to single-class firms, dual-class firms evaluate CEO performance over longer periods when awarding performance-vested stock grants.

Second, the board's choice of performance measures should reflect company strategy and what type of actions are expected from management (Ittner, Larcker and 
Rajan, 1997). The Informativeness Principle indicates that a measure is useful for contracting as long as it is incrementally informative about managerial efforts (Holmstrom, 1979).Both accounting measures and stock returns measures are reflective of managerial performance and commonly used in CEO performance evaluation. Prior research examines the use of accounting versus stock returns measures for purposes of awarding CEOs' cash bonuses (Lambert and Larcker 1987; Baker 1987; Core et al. 2003). The evidence generally suggests that cash bonus plans put more weight on market measures than on accounting measures when accounting measures are noisier, which is consistent with prediction of contract theory (Banker and Datar, 1989).

If CEOs are evaluated using stock market-based performance measures, then they would be incentivized to pursue short-term market returns rather than to focus on longterm strategic goals. Thus, greater reliance on market-based performance measures among dual-class firms would contradict the purpose of protecting CEOs' long-term strategic decision making from market pressures. As a result, I hypothesize that if dualclass firms have a long-term orientation, then they will be less likely to use market-based measures to benchmark their CEOs’ performance.

H2: Compared to single-class firms, dual-class firms are less likely to use stockbased measures when awarding performance-vested stock grants.

Finally, relative performance evaluation (RPE) can be incorporated in performancevested stock awards to benchmark the firm's stock return performance or accounting performance against a group of peer firms (Holmstrom, 1982; Albuquerque, 2009; Gong et al. 2011).Use of RPE might filter out exogenous noise (common shocks) that is unrelated to actions undertaken by the firm, thus enhancing the link between performance 
measurement and the efforts and actions of the CEOs. However, RPE measures may be problematic in dual-class firms.

If a dual-class structure is established to protect managers from short-term market interference with respect to their unique long-term innovative or strategic business decisions, then it could be challenging for the board to identify an appropriate comparison group against which to benchmark managers' performance. Even if an appropriate peer group could be identified for a dual-class firm, the dual-class firm could wind up implicitly incorporating short-term oriented measures in its own evaluation process if firms in the peer group use short-term oriented performance measures for their executives. Hence, I hypothesize that:

H3: Compared to single-class firms, dual-class firms are less likely to use peerbased targets than single-class firms when awarding performance-vested stock grants. 
Chapter 3

SAMPLE SELECTION, VARIABLES, AND DESCRIPTIVE STATISTICS

\subsection{Sample Selection for the Dual-Class and Single-Class Samples}

In this study, the dual-class firm sample covers all the U.S. dual-class firms in the S\&P 1500 from 2007 to 2011. In order to obtain a comprehensive set of dual-class firms, I first construct a list of possible candidates from Compustat. From this candidate sample, I examine annual filings made with the Securities and Exchange Commission to confirm that the company actually has a dual-class stock structure. The final dual-class sample consists of 419 firms.

I proceed in two steps to match the dual-class sample with a control group of single-class firms. In the first step, I rely on coarsened exact matching (CEM), which ensures that the treatment and control samples have identical characteristics. This procedure maximizes the quality of matching at the cost of a reduced sample size because control firms with identical characteristics as treatment firms are not always available. A necessary step to ensure an exact match is to convert every continuous variable to a set of different intervals, with each interval represented by an indicator variable (Iacus, King, and Porro 2008). In my sample, CEM yields 339control firms with a single-class structure.

In the second step, I rely on propensity score matching (PSM) to find control observations for the remaining 80 dual-class firms (Guo and Fraser 2010). PSM still assures that the control sample has similar characteristics as the treatment sample. The main benefit of PSM is that it uses all available control variables and does not require continuous variables to be represented by indicator variables. The propensity score is the 
predicted value from a Logit model of the likelihood of receiving treatment as a function of the control variables, and it can be used as a measure of the similarity between the treatment firm and control firm.

\subsection{Variables}

In general, CEO compensation arrangements are comprised of multiple components, including base salary, cash bonuses, restricted stock grants, and restricted stock option grants. For grants of restricted stock, different vesting schemes are used: performance vesting and time vesting. For a traditional time-vesting stock award, a stock will simply vest upon the completion of a time-based service requirement (e.g., 3 year service-based vesting). Time-based vesting does not take performance into account; stock vests with the passage of time. On the other hand, vesting of performance-based stock awards occurs upon attainment of pre-established absolute or relative targets. Vesting requirements use measures of company performance. If CEO does not meet the requirements the company set forth for the performance evaluation period, the stock shares are typically forfeited to the company. Only performance-vesting stock awards explicitly incorporate performance measures for evaluation purposes.

I hand collect proxy statement data on the choice of performance measures used in CEO stock compensation. Vesting of stock grants to executives is triggered by performance-vesting provisions. The criteria for number of restricted stock units vested are contingent on one or more performance metrics. Therefore, the CEO stock compensation is the performance-vesting award. I classify performance metrics into the following seven broad categories following Gao, Hwang and Wu (2012): (i) stock 
returns; (ii) earnings and other bottom-line measures such as EPS, EPS growth, operating income, net income, and operating margin;(iii) accounting return measures such as return on equity (ROE) and return on assets (ROA); (iv) sales and sales growth; (v) cash flow; (vi) other financial measures, such as market share; and (vii) non-financial measures, such as customer satisfaction. Performance on any of these metrics can be evaluated against absolute targets or relative to the performance of a group of peers.

To test my hypotheses, I construct three main variables: STOCK is an indicator variable for the use of stock returns as one of the performance measures. PEERS is an indicator variable for relative performance evaluation on at least one of the performance measures. LENGTH describes how many years of a CEO's performance is assessed in terms of the designated metrics when awarding stock compensation.

I also use several control variables. OWN refers to CEO equity ownership, and measures the percentage of firm equity owned by the CEO. It is calculated as the number of shares owned by the CEO (with options excluded) divided by the number of common shares outstanding at the end of the fiscal year.CEO ownership is an important variable to control for in the matching process because it affects other compensation choices and at the same time is relatively high in dual-class firms.

SIZE is defined as the natural log of total assets. LEVERAGE is the debt-toequity ratio. $M T B$ is the market-to-book ratio, calculated as the market capitalization four months after fiscal year end divided by common equity. SALEGROW captures the firm's annual sales growth rate. For both the CEM and PSM matched samples, I also control for 
the 10 Fama-French 48 industries that differentiate the most between dual-class and single-class firms. ${ }^{3}$

Finally, I also include the following variables in descriptive statistics comparisons. $M V$ is market value, calculated as the number of common shares outstanding multiplied by the closing price at fiscal year end. CAPXS is equal to capital expenditures scaled by sales.

\subsection{Descriptive Statistics}

Table 1 reports descriptive statistics concerning characteristics of dual- and single-class firms. The matched single-class firms are similar to the dual-class firms at the median value in terms of size, leverage, ROE, market-to-book, and CEO equity ownership percentage, implying that my matching process has generated a control sample effectively. Dual-class firms tend to have lower sales growth, lower market value, less leverage, and lower profitability (ROE) compared to S\&P 1500 firms, but are similar in terms of size. However, dual-class firms have higher capital expenditures than S\&P 1500 firms.

Table 2 shows the adoption of performance-vesting and time-vesting stock awards among dual-class and single-class firms. Performance-based stock awards are relatively

\footnotetext{
${ }^{3}$ These industries are Communication, Petroleum and Natural Gas, Food Products, Printing and Publishing, Apparel, Pharmaceutical Products, Consumer Goods, Electrical Equipment, Machinery, and Entertainment. During the CEM matching, I transform Size, Leverage and Own into three indicator variables, respectively, and $R O E$ and MTB into two indicator variables, respectively. Ten industries are also controlled as indicator variables. The number of indicator variables for every continuous variable is determined by maximizing the explanatory power of the Logistic model of treatment.
} 
more frequently adopted in single-class firms. In addition, time-vesting stock awards are commonly used in both dual-class and single-class firms.

Figures 1 and 2 show that the distribution of CEO stock ownership in dual-class and single-class firms is similar. This is because my sample matching procedures selected single-class firms with the same or closest CEO ownership percentage as in the dual-class firms. In contrast, Figures 3 and 4 suggest the distribution of CEO stock ownership is different in the broader sample of S\&P 1500 firm. In particular, CEOs in S\&P 1500 firms are much less likely to have equity stakes exceeding $5 \%$ of firm stock. 
Chapter 4

\section{RESEARCH DESIGN AND RESULTS}

\subsection{Matching Analysis}

This section uses matching estimators to provide an analysis of how a dual-class structure affects the design of performance measures in performance-based stock awards. Matching estimators are increasingly used in executive compensation and performance measure research (Armstrong, Jagolinzer and Larcker 2010; Casas-Arce, Indjejikian and Matějka 2013). As discussed earlier, I match dual-class firms to a control sample of single-class firms in the S\&P 1500 firms with similar characteristics. The CEM and PSM designs control for all main characteristics of the firms except the horizon measures under investigation. Thus, employing these two matching procedures ensures identical or similar characteristics between the control sample and treatment sample. Since influential control variables are all included in the matching process, the in-sample homogeneity enables a direct contrast between dual-class and single-class firms in terms of matching estimators.

H1 predicts that dual-class firms use a longer performance evaluation period for CEOs' performance-vesting stock grants. I compare the length of the performance evaluation periods used by dual-class and single-class firms and find that, on average, dual-class firms evaluate CEO performance over a 2.35 year span, while single-class firms assess CEO performance over a 2.44 year span when awarding performance-vested stock compensation—a statistically insignificant difference $(\mathrm{p}$-value $=0.757)$. Therefore, the results of this test do not provide evidence that distinguishes between optimal contracting and managerial entrenchment. 
$\mathrm{H} 2$ predicts that compared to single-class firms, dual-class firms are less likely to use market-based measures when awarding performance-vesting stock grants.I find that only $8.8 \%$ of dual-class firms use market-based metrics, while $37.1 \%$ of single-class firms use them, indicating that market-based metrics are less likely to be used by dualclass firms relative to single-class firms. The difference in the adoption of market-based metrics between single-class and dual-class firms is statistically significant $(\mathrm{p}<0.001)$. This result suggests that, consistent with H2, dual-class firms shield their CEOs from short-term market fluctuations and enable them to pay more attention to long-term strategic development.

Finally, I compare the use of peer-based measures across dual-class and singleclass firms. H3 predicts that dual-class firms are less likely to adopt peer-based measures in performance-vested stock awards. Consistent with this hypothesis, I find that $6.9 \%$ of dual-class firms use peer-based metrics as compared to $26.4 \%$ of single-class firms. This result is consistent with the board adopting absolute measures to avoid the use of inappropriate peer companies as benchmarks.

\subsection{Regression Models}

In this section, I use an alternative research design to test my hypotheses. Matching methodology finds matched firms based on the characteristics of the variables matched. As supposed to PSM and CEM, logistic regression is able to control as many variables of interest as needed.

Specifically, I estimate separate regression models of performance measure choice as a function of dual-class structure using the following framework: 


$$
\begin{aligned}
\text { PMCHOICE }_{i}= & \alpha_{0}+\alpha_{1} \text { DUAL }_{i}+\alpha_{2} \text { SIZE }_{i}+\alpha_{3} \text { LEVERAGE }_{i}+\alpha_{4} \text { ROE }_{i}+\alpha_{5} \text { MTB }_{i} \\
& +\alpha_{6} \text { EBITVOL }_{i}+\alpha_{7} \text { GROWTH }_{i}+\alpha_{8} \text { OWN }_{i}+\alpha_{9} \text { STOCKP }_{i}+\varepsilon_{i}
\end{aligned}
$$

where the dependent variable is equal to a) the length of the performance period, as measured in years (LENGTH); b) whether the firm uses market-based metrics (STOCK); or c) whether the firm uses peer-based metrics (PEERS).As LENGTH is a continuous variable measured in years, the $L E N G T H$ model is estimated via ordinary least squares regression. The STOCK and PEERS models are estimated via logistic regression, as these variables are dichotomous.

The independent variables are as follows. DUAL is an indicator variable measuring if the firm has a dual class structure. I control for the factors shown in prior literature to be the most influential factors in adopting a dual-class stock structure, including firm size (SIZE), accounting ROE, the debt-to-equity ratio (LEVERAGE), and the market-to-book ratio (MTB). OWN is defined as percentage of total shares owned by the CEO with options excluded. The percentage gap in industry density between dual class and single class firms is very pronounced in ten industries, so these industries are controlled for in the regression. I also include year fixed effects. STOCKP is defined as the percentage of CEO stock compensation among the total compensation.

There might be an endogeneity issue in terms of OWN and STOCKP variables. Since these two variables are potentially predetermined simultaneously with dependent variables, they might be related to the error term. To address this possible endogeneity issue for variables $O W N$ and $S T O C K P$, I estimate two additional regressions for each 
model that omit $O W N$ or STOCKP. If the regressions show consistent results, then it means endogeneity is not a problem.

Hypothesis 1 predicts that dual-class firms build a longer performance assessment period into their CEOs’ performance-vesting stock grants than single-class firms do. Table 4 reports the empirical results of the LENGTH regressions, which test H1. The coefficient of DUAL in the full regression is statistically insignificant, and the additional regressions omitting $O W N$ and STOCKP show results consistent with those of the full regression. Overall, I find no significant differences in performance period length between dual and non-dual class firms. Thus, I find no evidence in support of either optimal contracting or managerial entrenchment since the length of the performance evaluation period appears to be unrelated to dual-class structure.

Hypothesis 2 predicts that dual-class firms are less inclined to use market-based performance measures for performance-vesting stock grants. Table 5 reports the empirical results estimating the effect of a dual class stock structure on the choice to use stock-market-based performance measures. Consistent with H2, DUAL's coefficient is negative and significant at the $1 \%$ level, and the supplemental regressions omitting $O W N$ and STOCKP yield similar results. These findings indicate that dual class firms are less likely to evaluate the CEO's performance based on stock-market targets for purposes of performance-contingent stock compensation.

Finally, Hypothesis 3 predicts that dual-class firms are less likely to use RPE to evaluate and benchmark CEOs’ performance. Hence, I anticipate the effect of the dualclass variable (DUAL) in the PEER regression to be negative. As shown in Table 6, the significantly negative coefficient for $D U A L$ indicates that dual-class firms are more 
inclined to use absolute performance measures than comparable single-class firms. This finding is consistent with the optimal contracting explanation of Hypothesis 3.In other words, identifying an appropriate set of peers for benchmark purposes maybe difficult for firm that has a unique and innovative business model. Hence, on average, dual-class firms are less likely to use RPE for long-term stock awards. This finding is also consistent with the hypothesis that when a firm adopts dual class stock structure, the likelihood for using absolute performance measures increases. Dual class firms are more inclined to protect CEOs' incentives to innovate, and therefore provide forms of compensation that shield their CEOs' long-term business decisions from market pressures. In this sense, dual-class firms' claims of long-term orientation appear justified. 
Chapter 5

\section{CONCLUSION}

The rationale for dual-class stock structures continues to be debated in the academic literature. This study revisits dual-class share structures to investigate whether such firms incentivize their CEOs using performance-based awards that incorporate longhorizon metrics. This paper is among the first to examine differences in performance measure usage between dual-class and single-class firms. Specifically, I examine the measures used for performance-contingent stock compensation for CEOs within dualclass firms and find evidence that a dual-class structure is associated with a lower probability of using stock market based performance measures and peer-based metrics relative to a single-class structure. Taken together, this evidence is consistent with the notion that CEOs in dual-class firms are shielded from short-term market pressures and provides some evidence in support of the optimal contracting perspective. However, I also find that the length of the performance evaluation period does not differ between dual-class and single-class firms. This result suggests that dual-class firms do not use shorter evaluation periods to ease their CEOs’ achievement of performance targets.

Caution is necessary in explaining these findings. I focus on one component of CEO compensation-performance-contingent equity awards—-because it is well suited to examining whether CEOs of dual-class firms are incentivized to belong-term or shortterm oriented. With the decline of stock option awards, multi-year bonus plans could be another channel for examining the performance evaluation horizon of dual-class firms. Furthermore, most performance evaluation periods in my sample are either one year or three years in length. The length of the performance evaluation period may be subject to 
the influence of compensation consultants who might offer the same suggestions to different companies, resulting in similar performance evaluation periods across firms. Future research could extend the sample size to further explore this issue. 


\section{REFERENCES}

Albuquerque A. 2009. Peer firms in relative performance evaluation. Journal of Accounting and Economics, 48 (2009), pp. 69-89.

Amoako-Adu B., V. Baulkaran, B. F. Smith, Executive compensation in firms with concentrated control: The impact of dual class structure and family management, 2011. Journal of Corporate Finance, December, 17 (5), pp. 1580-1594.

Armstrong, C. S., A. D. Jagolinzer, and D. F. Larcker. 2010. Chief Executive Officer Equity Incentives and Accounting Irregularities. Journal of Accounting Research 48, pp. 225-271.

Baker, G. P. Discussion of An Analysis of the Use of Accounting and Market Measures of Performance in Executive Compensation Contracts.Journal of Accounting Research (September 1987), pp. 14-17.

Banker, R. D. and Datar, S. M., 1989, Sensitivity, precision, and linear aggregation of signals for performance evaluation, Journal of Accounting Research, 27, pp. 2139.

Bebchuk, L. A., J. M. Fried, D. I. Walker, Managerial power and rent extraction in the design of executive compensation, 2002, The University of Chicago Law Review, Vol. 69, pp. 751-846.

Bebchuk, L. A., R. Kraakman, and G. Triantis (2000) Stock pyramids, cross-ownership and dual class equity: the mechanisms and agency costs of separating control from cash-flow rights, Concentrated Corporate Ownership, pp445-460. Edited by Randall K. Morck, University of Chicago Press.

Casas-Arce, P., R. Indjejikian, and M. Matějka. 2013. Information Asymmetry and the choice of Financial and Nonfinancial performance targets during an economic downturn. Working Paper.

Core J. E. and D. F. Larcker 2002. Performance consequences of mandatory increases in executive stock ownership, Journal of Financial Economics, Vol. 64, No. 3, pp. 317-340.

Claessens, S., S. Djankov, and L. Lang. 2000. The separation of ownership and control inEast Asian corporations. Journal of Financial Economics 58, pp. 81-112.

Dallas, L. 2012. Short-termism, the financial crisis, and corporate governance. Journal of Corporation Law. 37, pp. 264-298. 
Dimitrov, Valentin, and P. Jain, 2006, Recapitalization of One Class of Common Stock into Dual Class: Growth and Long-Run Stock Returns, Journal of Corporate Finance 12, pp. 342-366.

Francis J., K. Schipper and L. Vincent, 2005. Earnings and dividend informativeness when cash flow rights are separated from voting rights. Journal of Accounting and Economics. 39, pp. 329-360.

Gao Z., Y. Hwang and W. Wu, 2012. Contractual features of performance-bested executive equity compensation, Working Paper.

Gomez-Mejia and Wiseman. 1997, L. Gomez-Mejia, R. Wiseman, Journal of Management. 23(3), pp. 291-374.

Gompers P. A., J. Ishii and A. Metrick. 2010. Extreme governance: an analysis of dualclass firms in the United States. The Review of Financial Studies. 23(3), pp. 10511088.

Gong G., L. Y. Li and J. Y. Shin. 2011. Relative performance evaluation and related peer groups in executive compensation contracts. The Accounting Review, 86(3), pp. 1007-1043.

Guo, S., and M. W. Fraser. Propensity Score Analysis. Thousand Oaks: SAGE, 2010.

Grabke-Rundell and Gomez-Mejia. 2002. Arden, L. R. Gomez-Mejia, Power as a determinant of executive compensation. Human Resource Management Review 12(1), pp. 3-21.

Holmström B. 1979. Moral hazard and observability. Bell Journal of Economics 10 (1), pp. 74-91.

Holmström B. 1982. Moral hazard in teams. Bell Journal of Economics 13, pp. 324-340.

Iacus, S., G. King, and G. Porro. "Matching for Casual Inference without Balance Checking." Working paper, Harvard University, 2008.

Ittner, Christopher, D. F. Larcker and M. V. Rajan, 1997. The choice of performance measures in annual bonus contracts, The accounting Review, April, 1997, Vol. 72 No. 2, pp. 231-255.

Janakiraman S. R. Lambert and D. Larcker. 1992. An empirical investigation of the relative performance evaluation hypothesis. Journal of Accounting Research, 30 (1992), pp. 53-69. 
Lambert R. A. and Larcker D. F. 1987. An Analysis of the use of accounting and market measures of performance in executive compensation contracts. Journal of Accounting Research. 25: pp.85-125.

Larcker, D. F. and B. Tayan. 2011. Corporate Governance matters: a closer look at organizational choices and their consequences. Pearson Education, Inc.

Masulis R. W., C. Wang and F. Xie, 2009. Agency problems at dual-class companies. The Journal of Finance. Vol. LXIV, No. 4. pp. 1697-1727.

Mizik, N. 2010. The Theory and Practice of Myopic Management. Journal of Marketing Research, 47(4), pp. 594-611. 


\section{APPENDIX A}

EXCEPT FROM COUNCIL OF INSTITUTIONAL INVESTORS (CII)'S

CORRESPONDENCE 
CII follow-up letter to NYSE meeting on dual-class stock, by Ann Yerger, Dec. 10, 2012

"CII's primary concerns about the multi-class structures centers on the profound governance challenges created by these structures. Simply put: directors may be less empowered to actively oversee management and make course corrections when they can be elected or fired by founders and/or their descendants. " 


\section{APPENDIX B}

EXCERPT FROM YAHOO NEWS 
Google to split stock to keep power with founders, by Barbara Ortuyay, April 12, 2012

Google's founders argue that Google will be more successful if the company concentrates on its long-term vision.

Without change [issuing a new class of stock with no voting power], senior leaders would eventually lose their voting power. CEO Larry Page and fellow co-founder Sergey Brin said that would undermine "our aspiration for Google over the very long term."

"It's important to bear in mind that this proposal will only have an effect on governance over the very long term," Page and Brin wrote their letter to investors. ” It’s just that since we know what we want to do, there's no reason to delay the decision.” 
Table 1:

Descriptive Statistics for Dual-Class Firms, Single-Class Firms and S\&P 1500 Firms

\begin{tabular}{lccccccc}
\hline & dual & $\mathrm{N}$ & mean & s.d. & $\mathrm{p} 25$ & $\mathrm{p} 50$ & $\mathrm{p} 75$ \\
\cline { 2 - 7 } SIZE & & & & & & & \\
& 1 & 419 & 7.857 & 1.624 & 6.719 & 7.541 & 8.700 \\
& 0 & 419 & 8.014 & 1.796 & 6.674 & 7.814 & 9.027 \\
LEVERAGE & 1500 & 7500 & 7.987 & 1.669 & 6.763 & 7.856 & 9.010 \\
& 1 & 419 & 0.168 & 0.177 & 0.016 & 0.126 & 0.260 \\
& 0 & 419 & 0.183 & 0.192 & 0.012 & 0.153 & 0.267 \\
ROE & 1500 & 7500 & 0.184 & 0.170 & 0.027 & 0.155 & 0.291 \\
& 1 & 419 & -0.015 & 0.844 & 0.023 & 0.086 & 0.151 \\
& 0 & 419 & 0.030 & 1.470 & 0.028 & 0.096 & 0.191 \\
MTB & 1500 & 7500 & 0.091 & 2.569 & 0.047 & 0.109 & 0.177 \\
& 1 & 419 & 1.752 & 9.815 & 1.083 & 1.641 & 2.825 \\
& 0 & 419 & 2.813 & 4.942 & 1.192 & 1.873 & 3.112 \\
SALEGROW & 1500 & 7500 & 2.555 & 19.518 & 1.252 & 1.892 & 3.011 \\
& 1 & 419 & 5.215 & 18.129 & -2.652 & 4.590 & 13.002 \\
& 0 & 419 & 9.718 & 59.859 & -4.068 & 5.235 & 13.943 \\
MV & 1500 & 7500 & 7.353 & 28.509 & -3.129 & 5.963 & 14.889 \\
& 1 & 419 & 9374 & 26740 & 642 & 1574 & 4836 \\
& 0 & 419 & 10733 & 29529 & 733 & 1955 & 7598 \\
OWN & 1500 & 7500 & 10025 & 28954 & 725 & 1874 & 7026 \\
& 1 & 419 & 5.612 & 11.206 & 0.097 & 0.659 & 4.785 \\
& 0 & 419 & 4.036 & 8.786 & 0.115 & 0.384 & 1.974 \\
CAPXS & 1500 & 7500 & 1.790 & 5.064 & 0.108 & 0.323 & 1.013 \\
& 1 & 419 & 0.045 & 0.048 & 0.016 & 0.032 & 0.053 \\
& 0 & 419 & 0.052 & 0.089 & 0.017 & 0.029 & 0.049 \\
& 1500 & 7500 & 0.049 & 0.078 & 0.014 & 0.025 & 0.039 \\
\hline & & & & & & &
\end{tabular}

SIZE is defined as the natural log of total assets. ROE is annual return on equity for the sample company. LEVERAGE is the debt-to-equity ratio. MTB is the market-to-book ratio, calculated as the market capitalization four months after fiscal year end divided by common equity. SALEGROW captures the firm's annual sales growth rate. MV is market value, calculated as the number of common shares outstanding multiplied by the closing price at fiscal year end. $O W N$ refers to CEO equity ownership, and measures the percentage of firm equity owned by the CEO. It is calculated as the number of shares owned by the CEO (with options excluded) divided by the number of common shares outstanding at the end of the fiscal year. CAPXS is equal to capital expenditures scaled by sales. 
Table 2:

CEO Compensation Contract Comparison for Dual-Class and Single-Class Firms

\begin{tabular}{lccccccc}
\hline & dual & $\mathrm{N}$ & mean & s.d. & $\mathrm{p} 25$ & $\mathrm{p} 50$ & $\mathrm{p} 75$ \\
\cline { 2 - 8 } PERFORMANCE & 1 & 419 & 0.384 & 0.487 & 0 & 0 & 1 \\
& 0 & 419 & 0.539 & 0.499 & 0 & 1 & 1 \\
TIME-VESTING & 1 & 419 & 0.403 & 0.491 & 0 & 0 & 1 \\
SALARY & 0 & 419 & 0.482 & 0.500 & 0 & 0 & 1 \\
BONUS & 1 & 419 & 935.103 & 791.801 & 609.808 & 870 & 1000 \\
& 0 & 419 & 848.452 & 486.808 & 550 & 741.756 & 1000 \\
STOCK & 1 & 419 & 291.455 & 1228.438 & 0 & 0 & 0 \\
STOCKP & 0 & 419 & 446.258 & 2560.984 & 0 & 0 & 0 \\
& 1 & 419 & 2114.843 & 7193.6 & 0 & 648.543 & 1844.25 \\
DUALITY & 0 & 419 & 2141.778 & 3239.162 & 46.552 & 1038.96 & 2624.573 \\
& 1 & 419 & 0.239 & 0.293 & 0 & 0.195 & 0.360 \\
INDDIR & 0 & 419 & 0.329 & 0.412 & 0.032 & 0.270 & 0.468 \\
& 1 & 419 & 0.505 & 0.501 & 0 & 1 & 1 \\
& 0 & 419 & 0.611 & 0.488 & 0 & 1 & 1 \\
& 1 & 419 & 6.345 & 2.761 & 5 & 6 & 8 \\
& 0 & 419 & 7.271 & 2.302 & 6 & 7 & 9 \\
\hline
\end{tabular}

PERFORMANCEdescribes whether or not the sample firm adopts performance-vesting stock awards for its CEO compensation. Vesting of performance-based stock awards occurs upon attainment of pre-established absolute or relative targets of firm performance. TIME-VESTING describes whether or not the sample firm uses time-vesting stock awards for its CEO compensation. Time-vesting stock awards vest with the passage of time. SALARY is the CEO's base salary compensation. BONUSis the CEO's bonus compensation disclosed in the proxy statement. STOCKis the CEO's stock compensation. STOCKP is defined as the percentage of CEO stock compensation among the total compensation. DUALITYdescribes the dual role of CEO, and it is equal to 1 if CEO also holds the role of chairman of the board, and 0 otherwise.INDDIR describes board independence, and it is the number of independent directors. 
Table 3:

Propensity Score Matching Analysis on Performance Measure Choices

\begin{tabular}{lccccc}
\hline \multicolumn{6}{l}{ Panel A: Performance Evaluation Period Length } \\
\hline LENGTH & & & & & \\
& Obs & Mean & Difference & T-stat & P-value \\
Treated & 161 & 2.352 & -0.088 & -0.63 & 0.757 \\
Controls & 159 & 2.440 & & & \\
\hline
\end{tabular}

Panel B: Stock Market-based Performance Measures

\begin{tabular}{lccccc}
\hline STOCK & & & & & \\
& Obs & Mean & Difference & T-stat & P-value \\
Treated & 161 & 0.088 & -0.283 & -6.35 & 0.000 \\
Controls & 159 & 0.371 & & & \\
\hline
\end{tabular}

Panel C: Peers-based Performance Measures

\begin{tabular}{lccccc}
\hline PEERS & & & & & \\
& Obs & Mean & Difference & T-stat & P-value \\
Treated & 161 & 0.069 & -0.195 & -4.82 & 0.000 \\
Controls & 159 & 0.264 & & & \\
\hline
\end{tabular}

LENGTH describes how many years of a CEO's performance is assessed in terms of the designated metrics when awarding stock compensation.

STOCK is an indicator variable for the use of stock returns as one of the performance measures. PEERS is an indicator variable for relative performance evaluation on at least one of the performance measures. 
Table 4:

Regression Analysis on the Length of Performance Evaluation Period

\begin{tabular}{lccc|ccccccc}
\hline & Coef. & $\mathrm{z}$ & $\mathrm{p}$-value & Coef. & $\mathrm{z}$ & $\mathrm{p}$-value & Coef. & $\mathrm{z}$ & $\mathrm{p}$-value \\
\cline { 2 - 9 } DUAL & 0.006 & 0.040 & 0.965 & 0.012 & 0.090 & 0.926 & 0.015 & 0.120 & 0.908 \\
SIZE & 0.088 & 2.250 & 0.025 & 0.088 & 2.230 & 0.027 & 0.077 & 1.990 & 0.048 \\
LEVARAGE & -0.248 & -0.690 & 0.490 & -0.285 & -0.800 & 0.423 & -0.301 & -0.840 & 0.401 \\
ROE & 0.269 & 1.910 & 0.057 & 0.267 & 1.900 & 0.059 & 0.273 & 1.930 & 0.054 \\
MTB & -0.017 & -1.440 & 0.150 & -0.017 & -1.450 & 0.149 & -0.017 & -1.460 & 0.144 \\
EBITVOL & 0.022 & 0.990 & 0.324 & 0.022 & 1.000 & 0.317 & 0.020 & 0.880 & 0.379 \\
SALEGROW & -0.003 & -1.790 & 0.074 & -0.003 & -1.790 & 0.075 & -0.002 & -1.720 & 0.087 \\
OWN & 0.014 & 1.700 & 0.090 & 0.015 & 1.820 & 0.069 & & & \\
STOCKP & -0.143 & -0.830 & 0.404 & & & & -0.180 & -1.060 & 0.292 \\
CONS & 1.734 & 5.060 & 0.000 & 1.685 & 4.990 & 0.000 & 1.899 & 5.760 & 0.000 \\
Industry & Yes & & & Yes & & & Yes & & \\
controls & & & & 0.021 & & & 0.041 & & \\
Prob > F & 0.026 & & & 387 & & & 387 & & \\
Sample size & 387 & & & $3.12 \%$ & & & $2.55 \%$ & & \\
Adjusted R ${ }^{2}$ & $3.04 \%$ & & & & & & & & & \\
\hline
\end{tabular}

The dependent variable, $L E N G T H$, describes how many years of a CEO's performance is assessed in terms of the designated metrics when awarding stock compensation.DUAL is an indicator variable measuring if the firm has a dual class structure. SIZE is defined as the natural $\log$ of total assets. ROE is annual return on equity for the sample company. LEVERAGE is the debt-to-equity ratio. MTB is the market-to-book ratio, calculated as the market capitalization four months after fiscal year end divided by common equity. EBITVOL is earnings volatility, and measured as the standard deviation of annual earnings over prior five years. SALEGROW captures the firm's annual sales growth rate. MV is market value, calculated as the number of common shares outstanding multiplied by the closing price at fiscal year end. OWN refers to CEO equity ownership, and measures the percentage of firm equity owned by the CEO. It is calculated as the number of shares owned by the CEO (with options excluded) divided by the number of common shares outstanding at the end of the fiscal year. STOCKP is defined as the percentage of CEO stock compensation among the total compensation. 
Table 5:

\section{Logistic Model on the Use of Market-Based Performance Measures}

\begin{tabular}{lccc|ccc|ccc}
\hline & Coef. & $\mathrm{z}$ & $\mathrm{p}$-value & Coef. & $\mathrm{z}$ & $\mathrm{p}$-value & Coef. & $\mathrm{z}$ & $\mathrm{p}$-value \\
\cline { 2 - 9 } DUAL & -1.928 & -5.560 & 0.000 & -1.938 & -5.610 & 0.000 & -1.948 & -5.610 & 0.000 \\
SIZE & 0.222 & 2.620 & 0.009 & 0.223 & 2.660 & 0.008 & 0.259 & 3.090 & 0.002 \\
LEVARAGE & 0.783 & 1.010 & 0.311 & 0.888 & 1.160 & 0.247 & 0.866 & 1.140 & 0.254 \\
ROE & 0.800 & 1.320 & 0.188 & 0.763 & 1.260 & 0.206 & 0.746 & 1.230 & 0.220 \\
MTB & 0.008 & 0.170 & 0.862 & 0.012 & 0.260 & 0.794 & 0.011 & 0.240 & 0.809 \\
EBITVOL & 0.062 & 1.510 & 0.131 & 0.060 & 1.470 & 0.142 & 0.067 & 1.630 & 0.104 \\
SALEGROW & -0.004 & -1.340 & 0.180 & -0.004 & -1.360 & 0.174 & -0.004 & -1.410 & 0.157 \\
OWN & -0.095 & -2.090 & 0.037 & -0.098 & -2.190 & 0.028 & & & \\
STOCKP & 0.484 & 1.480 & 0.139 & & & & 0.569 & 1.730 & 0.084 \\
CONS & -2.804 & -3.650 & 0.000 & -2.616 & -3.490 & 0.000 & -3.362 & -4.520 & 0.000 \\
Industry & Yes & & & & & & & & \\
controls & & & & -166.990 & & & -169.547 & & \\
Log likelihood & -165.920 & & & 0.000 & & & 0.000 & & \\
Prob > chi ${ }^{2}$ & 0.000 & & & 387 & & & 387 & & \\
Sample size & 387 & & & $20.89 \%$ & & & $19.68 \%$ & & \\
Pseudo R ${ }^{2}$ & $21.39 \%$ & & & & & & & & \\
\hline
\end{tabular}

The dependent variable, STOCK, is an indicator variable for the use of stock returns as one of the performance measures.DUAL is an indicator variable measuring if the firm has a dual class structure. SIZE is defined as the natural $\log$ of total assets. $R O E$ is annual return on equity for the sample company. LEVERAGE is the debt-to-equity ratio. MTB is the market-to-book ratio, calculated as the market capitalization four months after fiscal year end divided by common equity. EBITVOL is earnings volatility, and measured as the standard deviation of annual earnings over prior five years. SALEGROW captures the firm's annual sales growth rate. MV is market value, calculated as the number of common shares outstanding multiplied by the closing price at fiscal year end. OWN refers to CEO equity ownership, and measures the percentage of firm equity owned by the CEO. It is calculated as the number of shares owned by the CEO (with options excluded) divided by the number of common shares outstanding at the end of the fiscal year. STOCKP is defined as the percentage of CEO stock compensation among the total compensation. 
Table 6:

Logistic Model on the Use of Peer-Based Performance Measures

\begin{tabular}{|c|c|c|c|c|c|c|c|c|c|}
\hline & Coef. & $\mathrm{Z}$ & p-value & Coef. & $\mathrm{Z}$ & p-value & Coef. & $\mathrm{Z}$ & p-value \\
\hline DUAL & -1.476 & -3.980 & 0.000 & -1.483 & -4.010 & 0.000 & -1.487 & -4.010 & 0.000 \\
\hline SIZE & 0.244 & 2.570 & 0.010 & 0.248 & 2.620 & 0.009 & 0.276 & 2.950 & 0.003 \\
\hline LEVARAGE & 0.968 & 1.110 & 0.266 & 1.049 & 1.230 & 0.220 & 1.074 & 1.260 & 0.209 \\
\hline ROE & 0.719 & 1.030 & 0.304 & 0.694 & 1.000 & 0.318 & 0.670 & 0.950 & 0.342 \\
\hline МТВ & 0.019 & 0.350 & 0.724 & 0.022 & 0.400 & 0.690 & 0.022 & 0.400 & 0.689 \\
\hline EBITVOL & -0.345 & -1.230 & 0.219 & -0.331 & -1.180 & 0.239 & -0.335 & -1.190 & 0.233 \\
\hline SALEGROW & 0.008 & 1.260 & 0.209 & 0.008 & 1.330 & 0.184 & 0.008 & 1.260 & 0.209 \\
\hline OWN & -0.069 & -1.520 & 0.129 & -0.072 & -1.580 & 0.114 & & & \\
\hline STOCKP & 0.271 & 0.670 & 0.502 & & & & 0.354 & 0.920 & 0.356 \\
\hline CONS & -3.378 & -3.770 & 0.000 & -3.312 & -3.730 & 0.000 & -3.858 & -4.460 & 0.000 \\
\hline $\begin{array}{l}\text { Industry } \\
\text { controls }\end{array}$ & Yes & & & Yes & & & Yes & & \\
\hline Log likelihood & -145.326 & & & -145.536 & & & -147.102 & & \\
\hline Prob $>$ chi $^{2}$ & 0.000 & & & 0.000 & & & 0.000 & & \\
\hline Sample size & 387 & & & 387 & & & 387 & & \\
\hline Pseudo $\mathrm{R}^{2}$ & $15.92 \%$ & & & $15.79 \%$ & & & $14.89 \%$ & & \\
\hline
\end{tabular}

The dependent variable,PEERS, is an indicator variable for relative performance evaluation on at least one of the performance measures.DUAL is an indicator variable measuring if the firm has a dual class structure. SIZE is defined as the natural log of total assets. ROE is annual return on equity for the sample company. LEVERAGE is the debt-to-equity ratio. MTB is the market-to-book ratio, calculated as the market capitalization four months after fiscal year end divided by common equity. EBITVOL is earnings volatility, and measured as the standard deviation of annual earnings over prior five years. SALEGROW captures the firm's annual sales growth rate. $\mathrm{MV}$ is market value, calculated as the number of common shares outstanding multiplied by the closing price at fiscal year end. OWN refers to CEO equity ownership, and measures the percentage of firm equity owned by the CEO. It is calculated as the number of shares owned by the CEO (with options excluded) divided by the number of common shares outstanding at the end of the fiscal year. STOCKP is defined as the percentage of CEO stock compensation among the total compensation. 
Figure 1: Distribution of CEO Stock Ownership for Dual-Class Firms

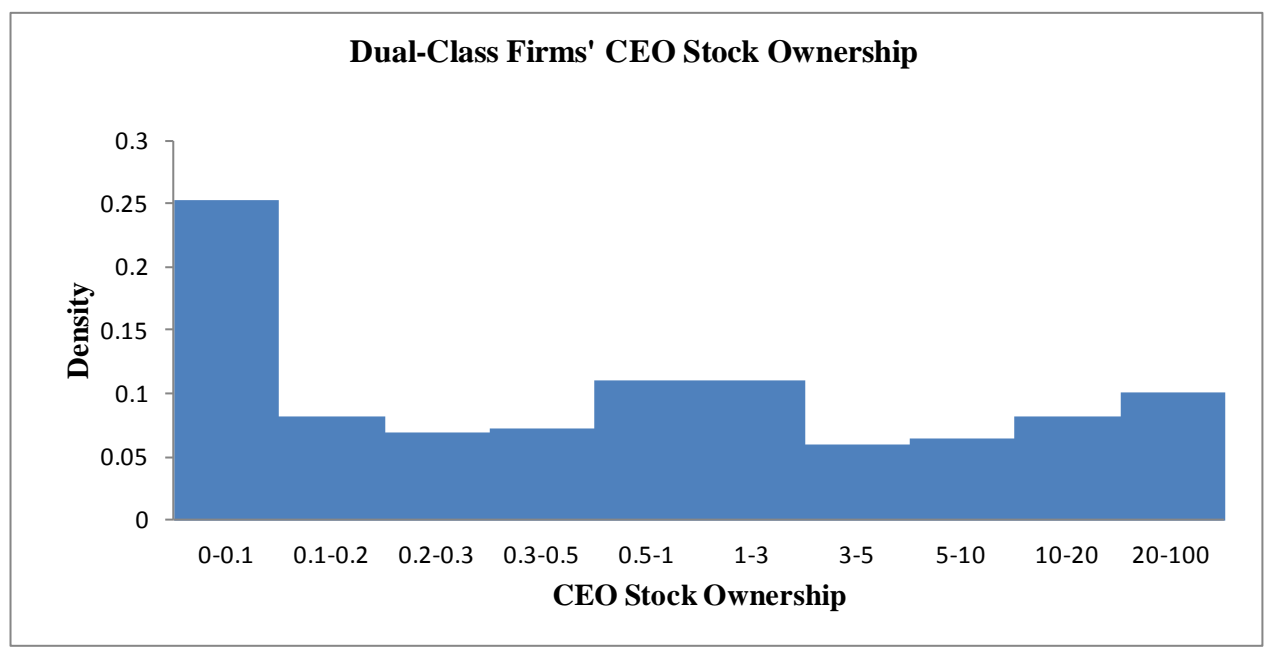

Figure 2: Distribution of CEO Stock Ownership for Single-Class Firms

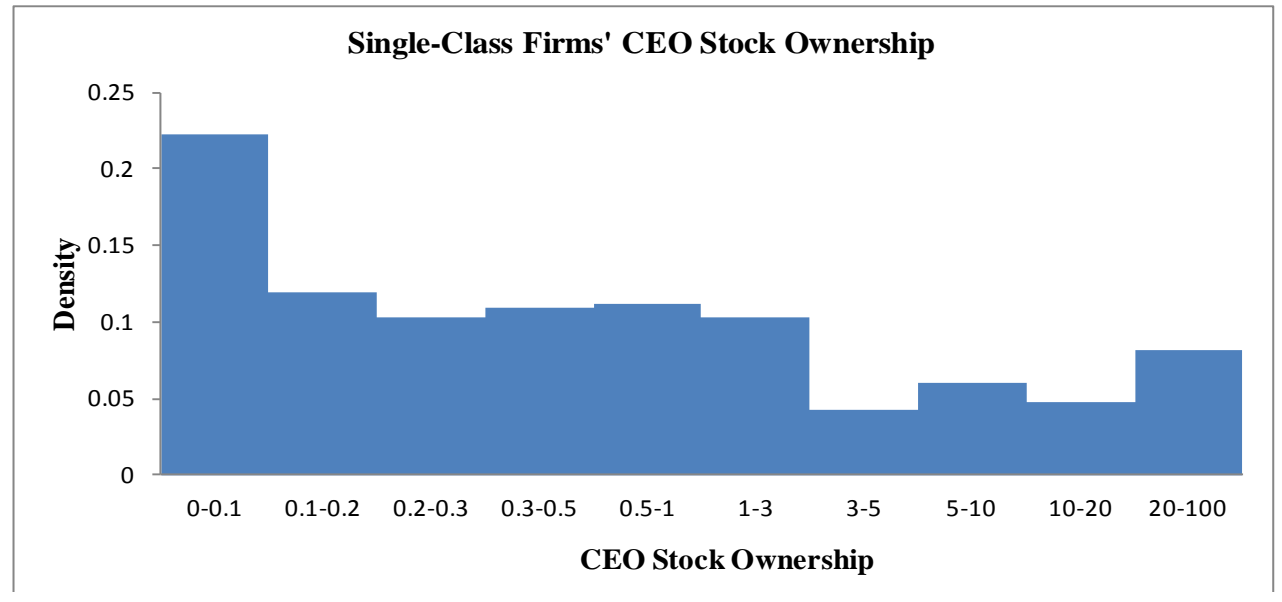

Figure 3: Distribution of CEO Stock Ownership for S\&P 1500 Firms

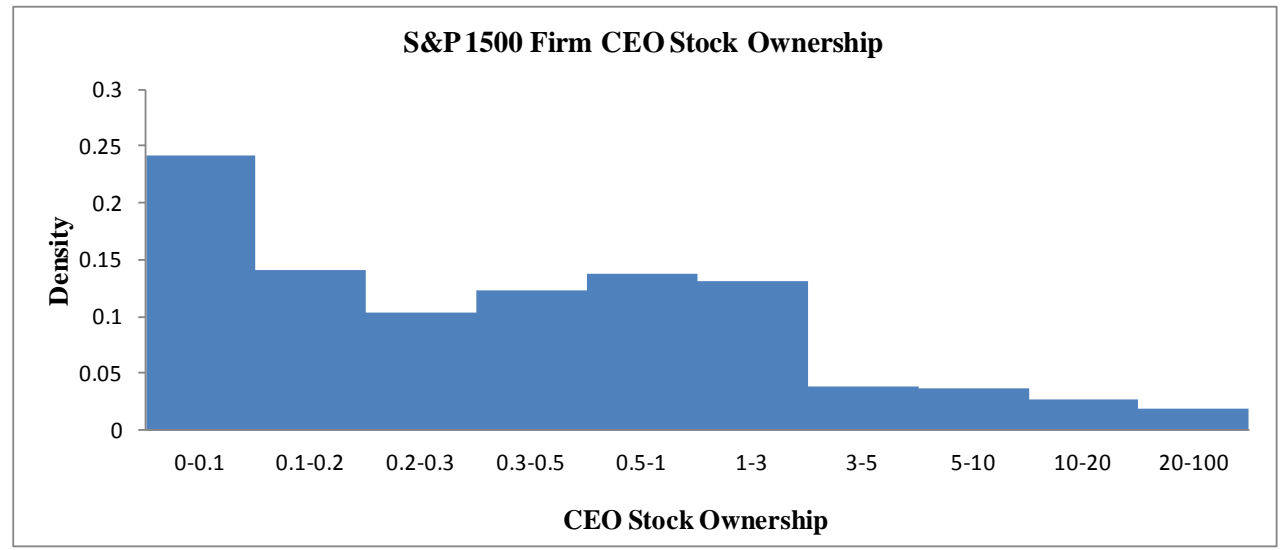


Figure 4:

Another presentation of distribution for dual-class, single-class firms and S\&P 1500 firms

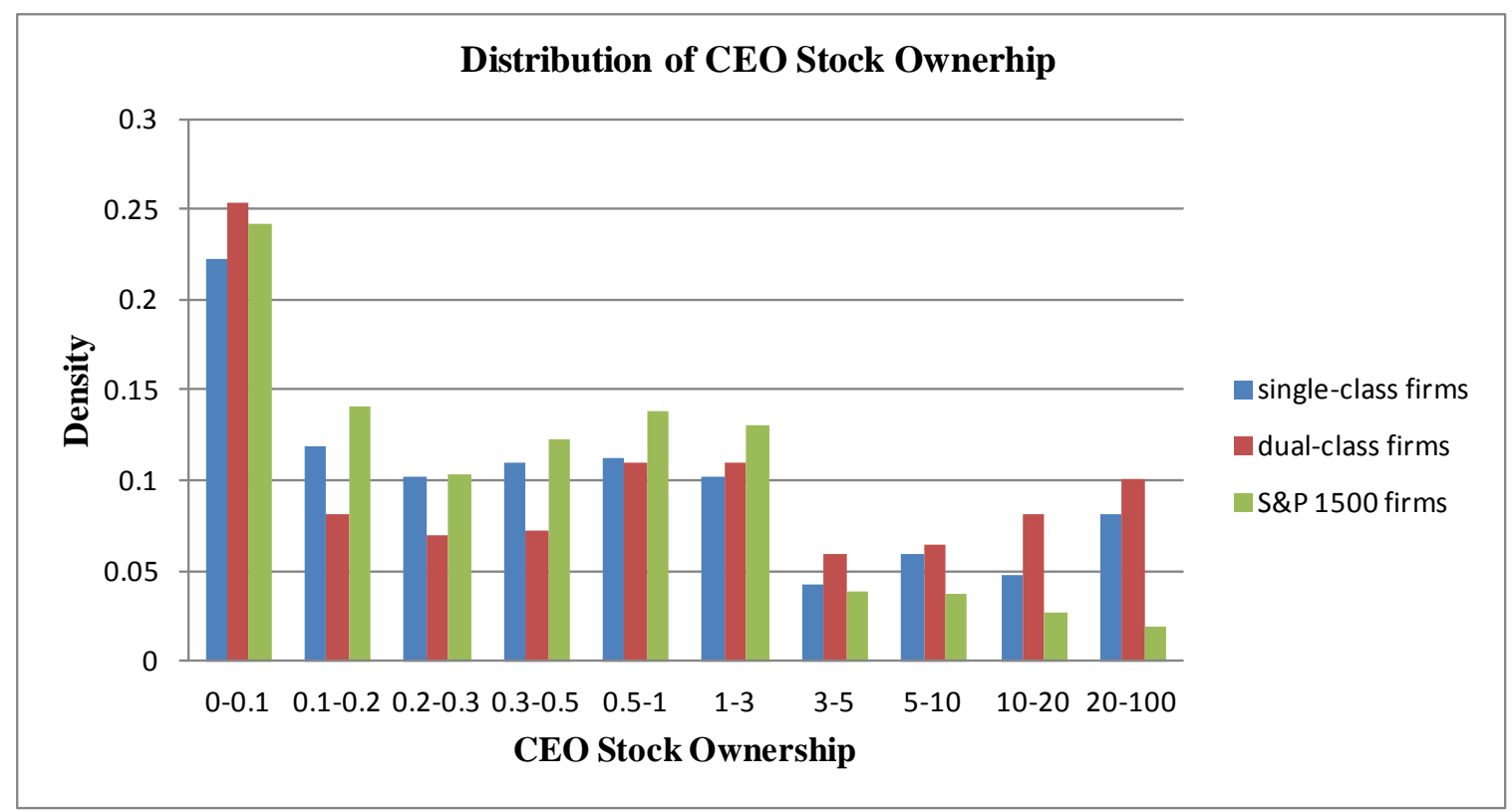

